Journal of The Indonesian Nutrition Association p-ISSN: 0436-0265 e-ISSN: 2528-5874

http://ejournal.persagi.org/index.php/Gizi_Indon

\title{
ASUPAN LEMAK, OBESITAS SENTRAL DAN HIPERKOLESTEROLEMIA PADA APARATUR SIPIL NEGARA (ASN) PEMERINTAH DAERAH PROVINSI BALI
}

\author{
Fat Intake, Central Obesity and Hypercholesterolemia in The Civil Apparatus \\ of The Regional Government of Bali Province
}

\author{
Ni Komang Wiardani, A.A.Ngurah Kusumajaya \\ Jurusan Gizi Politeknik Kesehatan Denpasar \\ E-mail: wiardani1603@yahoo.com
}

\section{ABSTRACT}

Central obesity is a type of obesity that is closely related to elevated cholesterol levels as one indicator of metabolic syndrome. Central obesity is found in many communities including ASN (government employee) along with changes in diet and community work patterns. The objective of this study was to investigate the relationship between fat intake, central obesity and cholesterol levels among government employee of the Provincial Office of Bali. This was an observational study with a cross-sectional design. The number of the subjects involved were 210 people, determined by multistage random sampling. The data collected were food intake, waist circumference and blood cholesterol level. Results showed that 58.1 percent were female and 41.9 percent male with age average of 43.6 years. The average total fat intake was $63.7 \mathrm{~g}$, saturated fat was $25.7 \mathrm{~g}$, cholesterol was $283.3 \mathrm{mg}$, waist circumference was $84.8 \mathrm{~cm}$ and total cholesterol was $183.6 \mathrm{mg} / \mathrm{dl}$. About 38.6 percent fat intakes were above adequacy, 44.8 percent subjects had central obesity and 34.3 percent of them had cholesterol level above normal (hypercholesterolemia). There was a significant correlation between total fat intake, saturated fat, cholesterol and central obesity with hypercholesterolemia status $(p<0.05)$ and central obesity was the main determinant of Hypercholesterolemia $(p<0.05)$. It was concluded that central obesity related to hypercholesterolemia among the employee of Bali Provincial Office.

Keywords: fat intake, central obesity, hypercholesterolemia, provincial office employee

\section{ABSTRAK}

Obesitas sentral merupakan jenis obesitas yang sangat erat hubungannya dengan peningkatan kadar kolesterol sebagai salah satu indikator sindroma metabolik. Obesitas sentral banyak ditemukan di masyarakat termasuk ASN seiring dengan adanya perubahan pada pola makan dan pola kerja masyarakat. Penelitian bertujuan mengetahui hubungan antara asupan lemak, obesitas sentral dan dengan kadar kolesterol pada Aparatur Sipil Negara Pemda Provinsi Bali. Penelitian ini merupakan penelitian observasional dengan rancangan cross sectional. Subjek penelitian adalah Aparatur Sipil Negara di lingkungan Pemda Provinsi Bali berjumlah 210 orang, yang ditentukan secara multi stage random sampling. Data yang dikumpulkan meliputi asupan makanan, berat badan dan tinggi badan, lingkar pinggang dan kolesterol darah. Data yang dikumpulkan diolah dan dianalisis dengan analisis bivariat dan multivariat. Hasil penelitian menunjukkan sebanyak 58,1 persen sampel berjenis kelamin perempuan dan 41,9 persen laki laki dengan umur rata rata 43,6 tahun. Rata rata asupan lemak total sehari $63,7 \mathrm{~g}$, lemak jenuh $25,7 \mathrm{~g}$, kolesterol $283,3 \mathrm{mg}$, lingkar pinggang $84,8 \mathrm{~cm}$ dan kadar kolesterol total $183,6 \mathrm{mg} / \mathrm{dl}$. Sebanyak 38,6 persen asupan lemak di atas kecukupan, 44,8 persen sampel mengalami obesitas sentral dan 34,3 persen mengalami hiperkolesterolemi dengan kadar kolesterol $>200 \mathrm{mg} / \mathrm{dl}$. Terdapat hubungan signifikan antara asupan lemak total, lemak jenuh, kolesterol dan obesitas sentral dengan status hiperkolesterolemia pada ASN Pemda Provinsi Bali $(p<0,05)$ dan analisis mulitivariat menunjukkan obesitas sentral merupakan determinan utama hiperkolesterolemia $(p<0,05)$. Dapat disimpulkan bahwa obesitas sentral merupakan determinan utama hiperkoleterolemia pada ASN Pemda Provinsi Bali. 


\section{PENDAHULUAN}

O besitas merupakan suatu kondisi gangguan keseimbangan energi dalam tubuh yang ditandai keseimbangan energi positif yang akhirnya disimpan dalam bentuk lemak di jaringan adiposa. ${ }^{1-3}$ Obesitas sentral merupakan salah satu jenis obesitas yang menggambarkan distribusi lemak di daerah abdomen yang dinilai dari ukuran lingkar pinggang (Waist Circumference) yaitu $>90 \mathrm{~cm}$ untuk laki laki dan $>80 \mathrm{~cm}$ untuk wanita. ${ }^{4,5}$ Permasalahan obesitas sentral saat ini berkembang pesat di masyarakat pada berbagai negara terutama pada usia dewasa. Data Riset Kesehatan Dasar (Riskesdas) 2013, menunjukkan peningkatan prevalensi obesitas sentral di Indonesia dari 18,8 persen tahun 2007 menjadi 26,6 persen tahun 20136 Prevalensi obesitas di Bali sekitar 35 persen yang terdiri dari laki laki 27,5 persen dan perempuan 43,4 persen. ${ }^{7}$ Distribusi lemak terutama di daerah visceral dan intra abdomen yang disebut obesitas sentral dianggap lebih berisiko karena sangat erat kaitannya dengan peningkatan kejadian kardiovaskuler, termasuk diabetes Melitus8,9. Timbunan lemak di daerah abdomen menimbulkan ganguan metabolisme dan menghambat pengaturan lipid sehingga menyebabkan peningkatan kadar kolesterol dalam darah. ${ }^{10,3}$ Penelitian di India, ${ }^{11}$ menunjukan kadar kolesterol lebih tinggi pada subjek yang memiliki IMT dan lingkar perut diatas normal. Penelitian Listiyana, dkk (2013) di kota Semarang menunjukkan ada hubungan antara obesitas sentral dengan kejadian Hiperkolesterolemia. ${ }^{11}$

Beberapa studi melaporkan hubungan berbagai faktor terhadap peningkatan obesitas sentral dan hiperkolesterolemia, seperti pola makan yang tidak sehat. 12,13,14 Adanya proses modernisasi dan akulturasi budaya, menyebabkan perubahan pola makan masyarakat di kota besar ke pola makan Barat. ${ }^{16}$ Masyarakat cenderung mengkonsumsi makanan siap saji yang banyak mengandung lemak, tinggi karbohidrat tapi miskin serat dan zat gizi lainnnya dengan alasan kepraktisan. Konsumsi energi dan lemak berlebihan akan menyebabkan asupan berlebih dan ketidak seimbangan zat gizi 17 Energi lebih banyak disimpan dalam tubuh dalam bentuk lemak sehingga berdampak pada peningkatan indeks masa tubuh, lingkar perut dan peningkatan kadar kolesterol darah. ${ }^{18}$ Beberapa penelitian menunjukkan bahwa makanan western dengan tinggi lemak dan rendah karbohidrat berhubungan dengan distribusi lemak tubuh dan obesitas sentral. ${ }^{2,12}$ Penelitian Yu, dkk,(2015) ${ }^{15}$ pada penduduk dewasa di Cina menemukan bahwa mereka yang mengonsumsi pola makan western memiliki lingkar pinggang lebih tinggi (rata rata $82,3 \mathrm{~cm}$ ) dibandingkan dengan pola makan tradisional $(78,8-81,4 \mathrm{~cm})$.

Aparatus Sipil Negara (ASN) merupakan sumber daya manusia di lingkungan pemerintah yang memiliki peran penting terhadap kinerja pemerintahan. Mereka dituntut memiliki integritas tinggi, menjalankan tugas dengan baik dan mampu menjadi pelayan masyarakat yang berkualitas. ${ }^{18}$ Oleh karena itu seorang ASN harus mampu menjaga kesehatan agar bisa bekerja secara optimal. Aparatur Sipil Negara (ASN) merupakan kelompok masyarakat yang juga memiliki risiko tinggi terhadap obesitas sentral dan hiperkolesterolemia. Adanya pola kerja monoton dan fasilitas teknologi infomasi dalam bekerja menyebabkan lebih banyak ASN yang bekerja dengan aktivitas kurang gerak (sedentary) dengan ditemani makanan camilan .Jika malas keluar pada saat jam makan, mereka tinggal memesan makanan siap saji dalam waktu yang cepat melalui layanan antar yang sangat mudah diakses. Disamping itu, kegiatan pertemuan yang sering diikuti ASN menyebabkan ASN lebih banyak duduk sambil menikmati hidangan makanan terutama sumber protein hewani yang tinggi lemak jenuh yang cenderung dikonsumsi secara berlebihan. Kondisi ini tanpa disadari mengarah pada kondisi obesitas sentral dan hiperkolesterolemia. Penelitian di Jepang terhadap pekerja dewasa usia di atas 45 tahun dengan status obes (IMT) $>25 \mathrm{~kg} / \mathrm{m}^{2}$, memiliki lingkar di atas normal (rata rata 98,8 $\mathrm{cm}$ pada pria dan $84,1 \mathrm{~cm}$ pada wanita) yang dikategorikan sebagai obesitas abdominal. ${ }^{19}$ Penelitian Ade (2013), ${ }^{20}$ pada PNS di Jawa Timur menunjukkan sebagian besar sampel baik laki laki maupun perempuan mengalami obesitas sentral walaupun tidak ditemukan hubungan antara pola makan dengan status obesitas pada sampel. Sedangkan penelitian (Cash, 2012) perilaku konsumsi tinggi lemak 
dan peningkatan derajat obesitas pada pekerja berhubungan dengan penurunan kualitas hidup dan produktivitas kerja di Seatle Amerika Serikat. ${ }^{21}$ Berdasakan latar belakang tersebut dirumuskan masalah "apakah ada hubungan antara asupan lemak, obesitas sentral dan hiperkolesterolemia pada Aparatur Sipil Negara (ASN) Pemerintah Daerah Provinsi Bali? Penelitian ini bertujuan untuk mengetahui hubungan antara asupan lemak dan obesitas sentral dengan kejadian hiperkolesterolemia pada ASN yang berkerja di Pemerintah Daerah Provinsi Bali. Penelitian diharapkan dapat memberikan informasi kepada ASN tentang pentingnya menjaga pola makan terutama asupan lemak sehingga terhindar dari obesitas sentral dan hipertkolesterolemia.

\section{METODE PENELITIAN}

Penelitian merupakan penelitian analitik observasional rangcangan cross sectional. Pengumpulan data variabel penelitian dilakukan sekali secara simultan melalui proses pengamatan, pengukuran dan mencatat informasi sesuai dengan hasil yang didapatkan di tempat penelitian, tanpa memberikan intervensi atau perlakuan pada subjek yang diteliti. ${ }^{22}$ Penelitian ini dilakukan di Kantor Dinas Aparatur Sipil Negara (ASN) di Satuan Kerja Perangkat Daerah (SKPD) Pemerintah Daerah Provinsi Bali dengan waktu penelitian selama 4 (empat bulan) mulai bulan Juli -Oktober 2017.

Populasi penelitian adalah ASN yang bekerja pada Dinas atau SKPD Pemda Provinsi Bali, sedangkan sampel adalah sebagian populasi yang memenuhi kriteria insklusi dan ekslusi yaitu teregistrasi sebagai ASN di lingkungan SKPD Provinsi Bali, laki-laki atau wanita, umur 25-55 tahun, dapat berkomunikasi dengan baik, bersedia diteliti dengan menandatangani inform consent. Penentuan besar sampel menggunakan teknik multi stage random sampling, yaitu dari seluruh SKPD Provinsi Bali dipilih 3 SKPD secara acak, dari 3 SKPD terpilih, dilakukan pengambilan sampel secara acak sebanyak 50 persen dari total ASN yang memenuhi kriteria Insklusi dan Eksklusi. Berdasarkan metode tersebut, maka diperoleh besar sampel sebanyak 210 orang.

Variabel penelitian meliputi asupan lemak, obesitas sentral dan kadar kolesterol total. Data yang dikumpulkan meliputi data karakteristik sampel, asupan lemak (lemak total, lemak jenuh dan kolesterol), lingkar pinggang dan kadar kolesterol darah total. Data karakteristik dikumpulkan dengan wawancara menggunakan kuesioner, asupan lemak dikumpulkan menggunakan food recall $1 \times 24$ jam dengan bantuan model makanan dan foto makanan, lingkar pinggang menggunakan pita lingkar pinggang elastis medline ketelitian $0,1 \mathrm{~cm}$, pengukuran kadar kolesterol total mengunakan alat multichek parameter metode enzimatis melalui pengambilan darah kapiler pada pagi hari. Data yang telah diperoleh selanjutnya di kompilasi, dipilah sesuai jenis data dan dilanjutkan dengan proses pengolahan data (editing, coding, cleaning).

Analisis data menggunakan program SPSS 15. Analisis data meliputi analisis univariat berupa data diskriptif dan distribusi frekuensi. Data asupan lemak (lemak total, lemak jenuh dan kolesterol) sehari dirata ratakan dibandingkan dengan anjuran kebutuhan sehari dan dikatagorikan menjadi $\leq$ anjuran dan > anjuran. Data lingkar pinggang dibandingkan dengan standar rujukan cutt of point lingkar pingggang untuk Asia Fasifik yaitu obesitas sentral jika lingkar pingang $>90 \mathrm{~cm}$ untuk pria dan $80 \mathrm{~cm}$ untuk wanita. ${ }^{4}$ Status Hiperkolesterolemia dinilai berdasarkan kadar kolesterol yang dikelompokkan menjadi dua yaitu hiperkolesterolemia jika kadar kolesterol $\geq$ $200 \mathrm{mg} / \mathrm{dl}$ dan normal jika $<200 \mathrm{mg} / \mathrm{dl}$. Hubungan antara variabel dianalisis menggunakan analisis bivariat khi- kuadrat dan multivariat regresi logistik dengan tingkat kepercayaan 95 persen $(\alpha=, 0,05)$

Penelitian ini telah mendapatkan ijin dan persetujuan dari Komisi Etik Fakultas Kedokteran Universitas Udayana/ RSUP Sanglah Denpasar dengan Nomor. 2027/UN.14.2/KEP/2017.

\section{HASIL}

\section{Karakteristik sampel}

Penelitian dilaksanakan di Kantor Satuan Kerja Perangkat Daerah (SKPD) Provinsi Bali dengan subjek penelitian adalah Aparatrur Sipil Negara (ASN). Jumlah subjek penelitian yang terlibat dalam penelitian yang telah memenuhi kriteria sebanyak 210 orang. Berdasarkan hasil 
penelitian, sebanyak 122 orang $(58,1 \%)$ sampel berjenis kelamin perempuan dan 88 sampel $(41,9 \%)$ berjenis kelamin laki laki. Rata- rata umur sampel adalah 43,6 tahun ( $\pm 8,03$ tahun) dengan umur terendah 25 tahun dan tertinggi 54 tahun. Jika dikelompokkan berdasarkan kelompok umur, proporsi terbesar berada pada kelompok umur 40-49 tahun yaitu sebanyak 50,5 persen dan paling sedikit pada kelompok umur $<30$ tahun $(9,5 \%)$. Berdasarkan tingkat pendidikan, sebagian besar sampel memiliki tingkat pendidikan dengan jenjang Diploma atau S1, yaitu sebanyak 129 orang $(61,4 \%)$, terdapat 12,9 persen sampel yang memiliki jenjang pendidikan magister ( S2) (Tabel 1).

\section{Asupan lemak}

Asupan lemak meliputi jumlah asupan lemak total, lemak jenuh dan asupan kolesterol makanan yang dikonsumsi oleh sampel dalam sehari. Hasil penelitian menunjukkan rata rata asupan lemak total sampel adalah $63,73 \mathrm{~g}$ $( \pm 7,09 \mathrm{~g})$, asupan lemak terendah $48,4 \mathrm{~g}$ dan tertinggi $63,7 \mathrm{~g}$. Rata rasa asupan lemak jenuh sebanyak $25,75 \mathrm{~g}( \pm 4,03 \mathrm{~g})$ dan rata rata asupan kolesterol makanan sebesar $283,3 \mathrm{mg}$ ( \pm 40,9 mg) dengan nilai terendah $198,0 \mathrm{~g}$ dan tertinggi 369,0 g. Apabila asupan lemak dibandingkan dengan anjuran kebutuhan sehari dengan menggunakan cut of 30 persen dari total energi sehari, sebagian besar sampel memiliki asupan lemak lebih dari anjuran (> 30 $\%$ total energi sehari) yaitu sebanyak 52,9 persen. Asupan lemak jenuh yang dianjurkan bagi seseorang adalah $<10$ persen dari total asupan energi sehari. ${ }^{3}$ Data hasil penelitian menunjukkan sebagian besar sampel mengonsumsi lemak jenuh di atas anjuran yaitu sebanyak 109 orang (51,9\%). Jika dilihat dari asupan kolesterol, proporsi sampel yang mengonsumsi kolesterol di atas anjuran konsumsi sehari sebanyak 100 orang $(47,6 \%)$ ( Tabel 1).

\section{Obesitas Sentral}

Obesitas sentral merupakan obesitas yang ditandai dengan adanya penimbunan lemak di daerah abdomen/visceral. Kriteria obesitas sentral ditentukan berdasarkan atas indikator lingkar pingang (LP). Hasil penelitian menunjukkan rata rata lingkar pinggang pada sampel perempuan adalah $81,8 \mathrm{~cm}( \pm 7,9 \mathrm{~cm})$ dan rata rata lingkar pinggang pada laki laki adalah $90,5 \mathrm{~cm} \quad( \pm 8,3 \mathrm{~cm})$. Seseorang dikatagorikan mengalami obesitas sentral jika LP $>90 \mathrm{~cm}$ pada laki laki dan $>80 \mathrm{~cm}$ pada perempuan. ${ }^{23,24}$ Berdasarkan kriteria tersebut, maka diperoleh hasil sebanyak 94 sampel (44,8 $\%)$ mengalami obesitas sentral, sedanglan apabila obesitas sentral dibedakan berdasarkan jenis kelamin, ditemukan sebanyak 47,5 persen sampel perempuan mengalami obesitas sentral dan 40,9 persen sampel laki laki mengalami obesitas sentral ( Tabel 1).

\section{Status Hiperkolesterolemia}

Kolesterol merupakan salah satu komponen lipid dalam plasma darah, baik yang bersumber dari kolesterol eksogen dari makanan dan kolesterol endogen. Menurut NCP ATP, kadar kolesterol yang dianggap normal adalah $<200 \mathrm{mg} / \mathrm{dl}$ dan kadar koleterol darah $\geq 200 \mathrm{mg} / \mathrm{dl}$ dinamakan dengan hiperkolesterolemia. ${ }^{25}$ Berdasarkan hasil pengukuran kolesterol darah sampel, diperoleh rata rata kadar kolesterol sampel adalah 183, $62 \mathrm{mg} / \mathrm{dl}$ ( $\pm 41,51 \mathrm{mg} / \mathrm{dl})$. Sebanyak 34,2 persen sampel memiliki kadar kolesterol diatas normal yang disebut hiperkolesterolemia (Tabel 2).

\section{Hubungan antara Karakteritik Asupan Lemak dengan Status Obesitas Sentral}

Untuk menganalisis hubungan dan perbedaan proporsi variabel penelitian karakteristisk dan asupan lemak dengan status obesitas sentral, dianalisis dengan menggunakan analisis Khi-kuadrat pada taraf siginifikan $5 \%$. Hasil analisis selengkapnya disajikan pada Tabel 1.

Berdasarkan analisis statistik khi-kuadrat, Tabel 1 menunjukkan tidak ada hubungan antara karakterisktik (umur, jenis kelamin dan tingkat pendidikan) dengan status obesitas sentral $(p>0,05)$, tetapi jika status obesitas dilihat dari asupan lemak, baik lemak total, lemak jenuh dan kolesterol ,hasil analisis menunjukkan terdapat hubungan yang signifikan antara asupan lemak total, lemak jenuh dan kadar kolesterol terhadap status obesitas sentral yang ditunjukkan oleh nilai $p<$ 0,05 dan interval kepercayaan $>1$. 
Hubungan Asupan lemak dan Obesitas Sentral dengan Status Hiperkolesterolemia.

Untuk melihat hubungan antara Status Hiperkolesterolemia yang dialami sampel, juga dianalisis dengan menggunakan anaisis khi_kuadrat. Hasil analisis menunjukkan tidak ada hubungan yang signifikan antara karakteristik dengan terjadinnya hiperkolesterolemia $(p>0,05)$. Sedangkan jika ditinjau dari asupan lemak dan status obesitas sentral, maka hasil analisis Khi-kuadrat menunjukkan bahwa terdapat hubungan yang siginifikan antara asupan lemak total, lemak jenuh, asupan kolaterol dan status obesitas sentral dengan kejadian hiperkolesterolemia dengan nilai $p<0,05$ dan interval kepercayaan $>1$. Hasil analisis disajikan pada Tabel 2.

\section{Analisis Multivariat Faktor Determinan Utama terhadap Hiperkolesterolemia}

Untuk mengetahui determinan utama hiperkolesterolemia digunakan analisis regresi logistik dengan memasukkan variabel yang signifikan pada analisis bivariat. Hasil analisis menunjukkan bahwa obesitas sentral memiliki nilai OR tertinggi dibandingkan variabel lainnya, yaitu 3,198 (Cl: 1,34- 4,99). Hal ini menyatakan bahwa obesitas sentral meningkatkan risiko hiperkolesterolemia 3,19 kali lebih tinggi dibandingkan yang tidak mengalami obesitas sentral dan berpengatruh positif terhadap kejadian obesitas sentral yang ditunjukkan oleh nilai $B$ exponen yang positif $(1,66)$, seperti ditunjukkan oleh Tabel 3. Dilihat dari nilai $p$ value uji signifikan wald, hanya status obesitas sentral yang memiliki nilai sig wald $0,000<0,05$, yang berarti status obesitas sentral memberikan pengaruh parsial siginifikan terhadap kejadian hiperkolesterolemia. Berdasarkan nilai prediktif pada persamaan regresi logistik $0,637>0,5$, obesitas sentral menjadi determinan utama atau prediktor terhadap hiperkolesterolemia.

Tabel 1

Status Obesitas Sentral berdasarkan Karakteristik dan Asupan Lemak

\begin{tabular}{|c|c|c|c|c|c|c|c|c|c|}
\hline & & Statı & Obesit & tas Se & & & & & \\
\hline & Variabel & Nor & & Obe & sentral & & & $\begin{array}{c}Q \\
\text { kuadrat }\end{array}$ & $\begin{array}{l}\text { P value } \\
\text { Cl. } 95 \%\end{array}$ \\
\hline & & $\mathrm{N}$ & $\%$ & $\mathrm{n}$ & $\%$ & $\mathrm{~N}$ & $\%$ & & \\
\hline Umur & & & & & & & & & \\
\hline- & $<30$ th & 12 & 5,7 & 8 & 3,8 & 20 & 9,5 & 1,20 & 0,70 \\
\hline- & $30-39$ th & 25 & 11,9 & 19 & 9,1 & 44 & 21,0 & & $(0,5-2,6)$ \\
\hline- & $40-49$ th & 60 & 28,6 & 46 & 21,9 & 106 & 50,5 & & \\
\hline- & $>49$ th & 19 & 9,0 & 21 & 10,0 & 40 & 19,0 & & \\
\hline Jenis $\mathrm{r}$ & Kelamin & 116 & 52,2 & 94 & 44,8 & 210 & 100,0 & & \\
\hline- & Laki- laki & 50 & 23,8 & 36 & 17,2 & 86 & 41,0 & 1,49 & 0,48 \\
\hline- & Perempuan & 66 & 31,4 & 58 & 27,5 & 124 & 59,0 & & $(0,7-2,1)$ \\
\hline Tingka & t Pendidikan & & & & & & & & \\
\hline- & SMU & 34 & 16,2 & 20 & 9,5 & 54 & 25,7 & 1,89 & 0,39 \\
\hline- & S1 & 67 & 31,9 & 62 & 29,5 & 129 & 61,4 & & $(0,8-3,2)$ \\
\hline- & Magister & 15 & 7,1 & 22 & 5,8 & 27 & 12,9 & & \\
\hline $\begin{array}{l}\text { Asupa } \\
\text { Total }\end{array}$ & n Lemak & & & & & & & & \\
\hline- & $\leq$ Anjuran & 77 & 36,7 & 34 & 16,2 & 111 & 52,9 & 19,01 & $0,000^{*}$ \\
\hline- & > Anjuran & 39 & 18,5 & 60 & 28,6 & 99 & 47,1 & & $(1,9-6,1)$ \\
\hline $\begin{array}{l}\text { Asupa } \\
\text { Jenuh }\end{array}$ & n Lemak & & & & & & & & \\
\hline- & $\leq$ Anjuran & 72 & 34,3 & 29 & 13,8 & 101 & 48,1 & 20,27 & $0,000^{*}$ \\
\hline & $>$ Anjuran & 44 & 21,0 & 65 & 30,9 & 109 & 51,9 & & $(2,0-6,5)$ \\
\hline Asupa & n kolesterol & & & & & & & & \\
\hline- & $\leq$ Anjuran & 75 & 35,7 & 35 & 16,7 & 110 & 52,4 & 15,65 & $0,000^{*}$ \\
\hline- & $>$ Anjuran & 41 & 19,5 & 59 & 28,1 & 100 & 47,6 & & $(1,7-5,4)$ \\
\hline
\end{tabular}


Tabel 2

Status Hiperkolesterolemia Berdasarkan Karakteristik, Asupan Lemak dan Obesitas Sentral

\begin{tabular}{|c|c|c|c|c|c|c|c|c|}
\hline \multirow{3}{*}{ Variabel } & \multicolumn{4}{|c|}{ Status Hiperkolesterolemia } & \multirow{2}{*}{\multicolumn{2}{|c|}{ Total }} & \multirow{3}{*}{$\begin{array}{c}\text { Khi- } \\
\text { kuadrat }\end{array}$} & \multirow{3}{*}{$\begin{array}{l}\text { P value } \\
\text { (Cl:95\%) }\end{array}$} \\
\hline & \multicolumn{2}{|c|}{ Normal } & \multicolumn{2}{|c|}{ Hiperkolesterolemia } & & & & \\
\hline & $\mathrm{n}$ & $\%$ & $\mathrm{n}$ & $\%$ & $\mathrm{~N}$ & $\%$ & & \\
\hline \multicolumn{9}{|l|}{ Umur } \\
\hline$-\quad<30$ th & 14 & 6,6 & 6 & 2,9 & 20 & 9,5 & \multirow[t]{4}{*}{2,34} & 0,50 \\
\hline$-\quad 30-39$ th & 32 & 15,3 & 12 & 5,7 & 44 & 21,0 & & $(0,22-2,3)$ \\
\hline - $\quad 40-49$ th & 69 & 32,9 & 37 & 17,6 & 106 & 50,5 & & \\
\hline$->49$ th & 23 & 10,9 & 17 & 8,1 & 40 & 19,0 & & \\
\hline \multicolumn{9}{|l|}{ Jenis Kelamin } \\
\hline - Laki- laki & 51 & 24,3 & 35 & 16,7 & 86 & 41,0 & \multirow[t]{2}{*}{2,65} & 0,08 \\
\hline - Perempuan & 87 & 41,4 & 37 & 17,6 & 124 & 59,0 & & $(0,34-1,1)$ \\
\hline \multicolumn{9}{|l|}{ Tingkat Pendidikan } \\
\hline - SMU & 37 & 17,6 & 17 & 8,1 & 54 & 25,7 & \multirow[t]{3}{*}{1,78} & 0,45 \\
\hline$-\quad s 1$ & 83 & 39,5 & 46 & 21,9 & 129 & 61,4 & & $(0,46-1,90$ \\
\hline - Magister & 18 & 8,6 & 9 & 4,3 & 27 & 12,9 & & \\
\hline \multicolumn{9}{|l|}{ Asupan Lemak Total } \\
\hline$-\quad \leq$ Anjuran & 82 & 39,0 & 29 & 13,8 & 111 & 52,8 & \multirow[t]{2}{*}{6,95} & $0,008^{*}$ \\
\hline - $>$ Anjuran & 56 & 26,7 & 43 & 20,5 & 99 & 47,2 & & $(1,2-3,8)$ \\
\hline \multicolumn{9}{|l|}{ Asupan Lemak Jenuh } \\
\hline$-\quad \leq$ Anjuran & 76 & 36,2 & 25 & 11,9 & 101 & 48,1 & \multirow[t]{2}{*}{7,85} & $0,005^{*}$ \\
\hline - $>$ Anjuran & 62 & 29,5 & 47 & 22,4 & 109 & 51,9 & & $(1,4-4,1)$ \\
\hline \multicolumn{9}{|l|}{ Asupan kolesterol } \\
\hline$-\leq$ Anjuran & 84 & 40,0 & 26 & 12,4 & 110 & 52,4 & \multirow[t]{2}{*}{11,62} & $0,001^{*}$ \\
\hline - $>$ Anjuran & 54 & 25,7 & 46 & 21,9 & 100 & 47,6 & & $(1,5-4,9)$ \\
\hline \multicolumn{9}{|l|}{ Obesitas Sentral } \\
\hline - Normal & 96 & 45,7 & 20 & 9,5 & 116 & 55,2 & \multirow[t]{2}{*}{6,95} & $0,008^{*}$ \\
\hline - Obesitas Sentral & 42 & 20,0 & 52 & 24,8 & 94 & 44,8 & & $(1,4-5,2)$ \\
\hline
\end{tabular}

Tabel 3

Analisis Multivariat Determinan Utama Hiperkolesterolemia

\begin{tabular}{|c|c|c|c|c|c|c|c|c|}
\hline \multirow[b]{2}{*}{ Variabel } & \multirow[t]{2}{*}{$B$} & \multirow[t]{2}{*}{ SE } & \multirow[t]{2}{*}{ Wald } & \multirow[t]{2}{*}{$\mathrm{df}$} & \multirow[t]{2}{*}{ Sig } & \multirow[t]{2}{*}{ OR } & \multicolumn{2}{|c|}{$95 \% \mathrm{Cl}$} \\
\hline & & & & & & & $\begin{array}{l}\text { Lower } \\
\text { Bound }\end{array}$ & $\begin{array}{l}\text { Upper } \\
\text { Bound }\end{array}$ \\
\hline $\begin{array}{l}\text { Status Obesitas } \\
\text { Sentral }\end{array}$ & 1,66 & 0,345 & 21,45 & 1 & 0,00 & 3,198 & 1,34 & 4,990 \\
\hline $\begin{array}{l}\text { Asupan Lemak } \\
\text { Total }\end{array}$ & 0,123 & 0,63 & 0,038 & 1 & 0,86 & 1,131 & $-1,107$ & 1,043 \\
\hline $\begin{array}{l}\text { Asupan lemak } \\
\text { Jenuh }\end{array}$ & $-0,27$ & 0,55 & 0,02 & 1 & 0,91 & 0,97 & $-1,137$ & 1,025 \\
\hline Asupan Kolesterol & 0,881 & 0,46 & 8,175 & 1 & 0,05 & -0.98 & $\therefore 1,704$ & 0,114 \\
\hline $\begin{array}{l}\text { Frekuensi Konsumsi } \\
\text { Lemak }\end{array}$ & 0,22 & 0,38 & 0,03 & 1 & 0,86 & 1,022 & $-0,778$ & 0.662 \\
\hline Konstant & 1,10 & 0,295 & 3,279 & 1 & 0,08 & 1,301 & & \\
\hline
\end{tabular}




\section{BAHASAN}

Obesitas sentral yang ditandai oleh penumpukan lemak di daerah abdominal merupakan faktor risiko terjadinya penyakit kardiovaskular yang didahului oleh adanya gejala sindroma metabolik dengan salah satu indikator yaitu hiperkolesterolemia. Penilaian obesitas sentral dapat dilakukan dengan menggunakan pengukuran terhadap lingkar pinggang atau waist circumference yaitu $>90$ $\mathrm{cm}$ pada laki laki dan $>80 \mathrm{~cm}$ pada wanita. 24,15 Penelitian yang dilakukan terhadap 210 subjek Aparatur Sipil Negara (ASN) Pemerintah Daerah Provinsi Bali yang terdiri dari 41,9 persen laki laki dan 52,1 persen perempuan, menunjukkan rata rata lingkar pingang pada wanita $81,8 \mathrm{~cm}$ dan $90,5 \mathrm{~cm}$ pada laki laki. Hasil penelitian ini lebih rendah jika dibandingkan penelitian Bowen et al., (2015) pada penduduk Michigan yaitu Rasio Pingggang Panggul atau Waist Hip Ratio (WHR ) pada laki laki sebesar $0,94 \mathrm{~cm}$ dan perempuan $0,84 \mathrm{~cm}$. Penelitian Wiardani et al,(2011) menemukan rata rata lingkar pinggang pada wanita dewasa yang mengalami sindroma metabolik di Denpasar adalah $92,2 \mathrm{~cm} .{ }^{26}$ Walaupun rata rata ukuran lingkar pinggang lebih rendah, tetapi hasil penelitian menunjukkan bahwa sebanyak 44,2 persen sampel memiliki obesitas sentral dan berdasarkan jenis kelamin, proporsi wanita yang mengalami obesitas sentral lebih tinggi yaitu $47,5 \%$ dan pada laki laki sebanyak 40,9 persen, tetapi tidak terdapat hubungan signifikan antara jenis kelamin dan obesitas sentral $(p<0,05)$. Hasil penelitian ini lebih tinggi jika dibandingkan penelitian Dwipayana (2011), yang menemukan prevalensi obesitas sentral pada penduduk di Bali sebesar 35 persen (43,4 persen pada perempuan dan 27,5 persen pada laki laki. ${ }^{7}$ Penelitian Bo Xi et al (2012) di China menunjukkan prevalensi obesitas sentral 45,9 persen pada wanita dan 27,8 persen pada pria, ${ }^{28}$ tetapi hasil penelitian ini lebih rendah dari hasil penelitian Listiyana di Semarang pada wanita dewasa yang menunjukkan 61,7 persen sampel mengalami obesitas sentral 11 dan penelitian Wiardani pada wanita dewasa di Kota Denpasar dengan obesitas sentral 51,8 persen. ${ }^{28}$ Beberapa studi menyebutkan bahwa peningkatan proporsi obesitas sentral yang lebih tinggi pada wanita, selain disebabkan oleh faktor gaya hidup, secara fisiologis disebabkan oleh proporsi lemak pada wanita dewasa lebih tinggi dibandingkan laki laki dan memasuki usia 40 tahun, wanita mulai mengalami penurunan produksi hormon yang memperlambat laju metabolisme sehingga energi yang dihasilkan lebih banyak disimpan dalam bentuk lemak. ${ }^{29}$

Obesitas sentral paling banyak ditemukan pada umur 40-59 tahun walaupun secara statistik terdapat hubungan yang tidak signifikan $(p<0,05)$ (Tabel 3). Obesitas sentral mulai ditemukan pada usia yang lebih muda erat kaitannya dengan perubahan pola makan pada masyarakat. Peningkatan obesitas sentral selama beberapa dekade terjadi seiring dengan adanya transisi demografi yang mengubah gaya hidup masyarakat. Obesitas sentral berkaitan dengan dengan perubahan pola makan terutama peningkatan konsumsi lemak sebagai sumber energi dengan densitas energi tinggi. ${ }^{30}$ Hasil penelitian menunjukkan bahwa sebanyak 52,9 persen sampel mengonsumsi lemak melebihi anjuran ( $>30 \%$ total konsumsi energi sehari). Tingginya proporsi konsumsi lemak total juga diikuti dengan proporsi yang cukup tinggi pada asupan lemak jenuh dan kolesterol yang di atas anjuran yaitu 51,9 persen untuk lemak jenuh dan 47,6 persen untuk asupan kolesterol. Beberapa hasil penelitian terkait dengan konsumsi lemak cukup bervariatif. Penelitian pada pekerja wanita di California menunjukan bahwa sebanyak 53 persen subjek mengkonsumsi lemak >35 persen total energi sehari, ${ }^{31}$ dan Bowen dkk $(2015)^{2}$, menemukan rata rata prosentase konsumsi energi bersumber dari lemak, pada penduduk India Michigan sekitar 25,1 persen. Sedangkan di Indonesia, penelitian Arinda pada Pegawai Negeri Sipil (PNS) di Jember menunjukkan bahwa rata rata konsumsi lemak pada PNS obes lebih tinggi dari konsumsi PNS dengan status gizi normal dan penelitian Listiyana di semarang sebanyak 55,6 persen sampel mengonsumsi kolesterol $\geq 300$ $\mathrm{mg} / \mathrm{hari} \cdot 32$

Lemak merupakan salah satu makronutrien sebagai sumber energi utama setelah karbohidrat dan merupakan cadangan energi yang sangat efisien di dalam tubuh. Anjuran konsumsi lemak berkisar antara 25-30 persen dari total energi sehari, asupan lemak jenuh 10 persen total energi sehari dan kolesterol $\leq 300 \mathrm{mg}$ /hari. ${ }^{3}$ Konsumsi lemak dan kolesterol sampel yang melebihi anjuran, 
berasal dari makanan sumber lemak yang digoreng dan makanan siap saji yang memiliki densitas energi tinggi. Makanan tersebut banyak dikonsumsi sampel sebagai makanan camilan pada saat bekerja dan konsumsi saat pertemuan dan istirahat. Kelebihan asupan lemak dari makanan akan meningkatkan distribusi dan simpanan lemak dalam tubuh di jaringan adiposa khususnya di daerah abdominal dan intra abdominal yang dapat menimbulkan obesitas sentral. Hal ini terbukti dengan hasil penelitian yang menunjukan terdapat hubungan signifikan antara asupan lemak, total, lemak jenuh dan koletserol terhadap status obesitas sentral pada sampel $(p<0,05)$. Hasil penelitian ini didukung oleh penelitian lainnya yang juga menyatakan bahwa makanan western dengan tinggi lemak dan rendah karbohidrat berhubungan dengan peningkatan distribusi lemak tubuh, obesitas sentral dan sindroma metabolik. 2,12,30,28

Hiperkolesterolemia merupakan akibat dari peningkatan asupan lemak baik lemak jenuh dan kolesterol serta obesitas sentral. Asupan lemak jenuh dan sumber kolesterol dari makanan yang dikonsumsi secara berlebihan dapat mempengaruhi kadar profil lipid seperti peningkatan kadar trigliserida dan kolesterol, walaupun produksi kolesterol tubuh hanya 25 persen bersumber dari kolesterol makanan yang dikonsumsi. ${ }^{33}$ Hasil penelitian menunjukkan terdapat hubungan antara konsumsi lemak, lemak jenuh dengan kadar kolesterol dari makanan terhadap kadar kolesterol total $(p<0,05)$. Sampel yang memiliki kadar kolesterol tinggi sebagian besar memiliki asupan lemak total, lemak jenuh dan kolesterol makanan melebihi anjuran. Hasil penelitian ini didukung oleh hasil penelitian lain yang menyatakan bahwa konsumsi makanan dengan kandungan lemak jenuh dan kolesterol tinggi seperti hamburger menurunkan kadar HDL kolesterol, meningkatkan kadar trigliserida walaupun tidak berdampak pada LDL kolesterol. 34,13

Obesitas sentral yang ditandai oleh timbunan lemak di daerah visceralsangat erat kaitannya dengan hiperkolesterolemia. Semakin banyak penimbunan lemak di rongga perut akan diikuti oleh meningkatnya kadar koleterol total dan kolesterol LDL yang dikenal dengan hiperkolesterolemia. ${ }^{35}$. Hasil penelitian menunjukkan bahwa terdapat hubungan signifikan antara status obesitas sentral dengan kejadian hiperkolesterolemia $(p<0,05)$ dan merupakan determinan utama hiperkolesterolemia. Penelitian Listiyana, dkk (2013) di kota semarang juga menunjukkan ada hubungan antara obesitas sentral dengan kejadian Hiperkolesterolemia. 12 Obesitas sentral yang bersifat menetap dalam jangka waktu lama akan menimbulkan sirkulasi lipid tidak normal dan gangguan metabolik yang disebut sindroma metabolik dengan salah satu indikatornya adalah hiperkolesterolemia sebagai faktor risiko utama aterosklerosis penyakit jantung koroner ${ }^{10,36}$.

\section{SIMPULAN DAN SARAN}

\section{Simpulan}

Hasil penelitian menunjukkan sebanyak 44,8 persen ASN Pemda Bali mengalami obesitas sentral, sebanyak 52,9 persen sampel memiliki asupan lemak lebih dari anjuran (> $30 \%$ total energi sehari ), 51,9 persen memiliki .asupan lemak jenuh diatas anjuran dan 47,3 persen asupan kolesterol diatas anjuran. Sebanyak 34,2 persen sampel mengalami hiperkolesterolemia yang ditandai oleh kadar kolesterol $>200 \mathrm{mg} / \mathrm{dl}$. Terdapat hubungan signifikan antara asupan lemak dengan status obesitas sentral, asupan lemak dengan hiperkoleterolemia dan obesitas sentral dengan status hiperkolesterolemia.

\section{Saran}

Diperlukan adanya peningkatan dan pemahaman kepada ASN tentang bahaya obesitas sentral dan hiperkolesterolemia. Diperlukan adanya edukasi yang berkala kepada ASN tetang perlunya menerapkan pola hidup yang sehat dengan gizi seimbang agar terhindar dari obesitas sentral dan hiperkolesterolemia.

\section{UCAPAN TERIMA KASIH}

Ucapan terimakasih disampaikan kepada Direktur Politeknik Kesehatan Denpasar, Pemerintah daerah provinsi Bali dan SKPD di lingkungan Pemda Provinsi Bali, ASN yang bersedia menjadi subjek penelitian dan para enumerator yang membanti proses pengumpulan data. 


\section{RUJUKAN}

1. Wang H, Wang J, Liu M-M, Wang D, Liu Y$Q$, Zhao $Y$, et al. Epidemiology of general obesity, abdominal obesity and related risk factors in urban adults from 33 communities of northeast china: the CHPSNE study. BMC Public Health [Internet]. 2012;12(1):967. Available from: http://bmcpublichealth.biomedcentral.com/ar ticles/10.1186/1471-2458-12-967

2. Bowen L, Taylor AE, Sullivan R, Ebrahim $S$, Kinra S, Krishna KR, et al. Associations between diet, physical activity and body fat distribution: a cross sectional study in an Indian population. BMC Public Health. 2015;15:281:2-12.

3. Nelm,Marcia., Sucher, Chateryn, Lacey , Karen., Roth SL. Nutrition Therapy and Pathofisiology [Internet]. Second Edi. USA: Yolando casio; 2011. 238-263 p. Available from: www//change age.com

4. Ramachandran A, Snehalatha C. Rising burden of obesity in Asia. J Obes. 2010;1:18.

5. Anuurad E, Shiwaku K, Nogi A, Kitajima K, Enkhmaa B, Shimono K, et al. The New BMI Criteria for Asians by the Regional Office for the Western Pacific Region of WHO are Suitable for Screening of Overweight to Prevent Metabolic Syndrome in Elder Japanese Workers. J Occup Health. 2003:45:335-43.

6. Kemnkes RI. Riskesdas Dalam Angka Indonesia tahun 2013 [Internet]. Trihono, Fahmi, Umar.Junadi, Purnawan., Sudomo, Suwandono, Agus., Sukasediati, Nani.,Herman S, editor. Jakarta: Badan Litbangkes Depkes Rl; 2013. 446 p. Available from: www.litbangkes.depkes.go.id

7. Dwipayana MP, Suastika K, Saraswati I, Gotera W, Budhiarta A, Sutanegara, et al. Prevalensi Sindroma Metabolik Pada Populasi Penduduk Bali, Indonesia. J Peny Dalam. 2011;12(1):1-5.

8. Gray LJ, Yates T, Davies MJ, Brady E, Webb DR, Sattar N, et al. Defining obesity cut-off points for migrant south asians. PLoS One. 2011;6(10):4-10.

9. Diets $H$. Prevention of Type 2 Diabetes through Lifestyle Modi fi cation: Is There a Role for. 2015;(4):665-73.

10. Bays HE, Toth PP, Kris-Etherton PM, Abate
$\mathrm{N}$, Aronne LJ, Brown WV, et al. Obesity, adiposity, and dyslipidemia: A consensus statement from the National Lipid Association. J Clin Lipidol [Internet]. 2013;7(4):304-83. Available from: http://dx.doi.org/10.1016/j.jacl.2013.04.001

11.Listiyana AD, Madriana; Prameswari GN. Obesitas Sentral Dan Kadar Kolesterol Darah Total. J Kesehat Masy [Internet]. 2013;9(1):37-43. Available from: http://journal.unnes.ac.id/nju/index.php/kem as

12. Shu L, Zheng PF, Zhang XY, Si CJ, Yu XL, Gao W, et al. Association between dietary patterns and the indicators of obesity among Chinese: A cross-sectional study. Nutrients. 2015;7(9):7995-8009.

13. Wiardani NK, Ngurah Kusumajaya AA, Wayan I, Arsana J. Macronutrient Intake and Metabolic Syndrome Status towards Tour Guide. Int J Health Sci (Qassim) [Internet]. 2018;2(1):29-44. Available from: http://sciencescholar.us/journal/index.php/ijh s\%0Ahttp://dx.doi.org/10.29332/ijhs.v2n1.97

14.Palupi MP. Faktor risiko obesitas sentral pada orang dewasa di indonesia. 2016;

15.Yu C, Shi Z, Lv J, Du H, Qi L, Guo Y, et al. Major dietary patterns in relation to general and central obesity among Chinese adults. Nutrients. 2015;7(7):5834-49.

16.Remesh A. Obesity: Pathophysiology and management-A pharmacological perspective. Asian J Pharm Clin Res. 2013;6(1):11-3.

17.Cizza, G.; Rother K. Beyond fast food and slow motion: Weighty contributors to the obesity epidemic. J Endocrinol Invest. 2012;35(2):236-42.

18.Anonim. Undang-undang Republik Indonesia No.5 tahun 2014 tentang Aparatur Sipil Negara [Internet]. Kementerian Hukum dan Hak Asasi Manusia. Jakarta; 2014. Available from:

sc.syekhnurjati.ac.id/esscamp/aturan/APAR ATUR_SIPIL_NEGARA_(ASN).pdf $\% 5 \mathrm{Cn}$

19. Traissac P, Pradeilles R, El Ati J, AounallahSkhiri H, Eymard-Duvernay S, Gartner A, et al. Abdominal vs. overall obesity among women in a nutrition transition context: geographic and socio-economic patterns of abdominal-only obesity in Tunisia. Popul Health Metr [Internet]. 2015;13(1):1-11. Available 
http://www.pophealthmetrics.com/content/13 $/ 1 / 1$

20. Dewi ANC, Mahmudiono T. Hubungan Pola Makan, Aktivitas Fisik, Sikap, dan Pengetahuan Tentang Obesitas dengan Status Gizi Pegawai Negeri Sipil di Kantor Dinas Kesehatan Provinsi Jawa Timur. J Media Gizi Indones. 2012;9(1):42-8.

21.Cash SW, Beresford SAA, Henderson JA, McTiernan A, Xiao L, Wang $C Y$, et al. Dietary and physical activity behaviours related to obesity-specific quality of life and work productivity: baseline results from a worksite trial. $\mathrm{Br} J$ Nutr [Internet]. 2012;108(6):1134-42. Available from: http://www.journals.cambridge.org/abstract_ S0007114511006258

22.Sudigdo Sastroasmoro SI. Dasar dasar Metode penelitian Klinins. 4th ed. Jarta: Sagung Seto; $2011.518 p$.

23.Bhurosy $T$, Jeewon R. Overweight and obesity epidemic in developing countries: A problem with diet, physical activity, or socioeconomic status? Sci World J. 2014;2014.

24.WHO. Obesity and Overweight .WHO Fact Sheet.N311 [Internet]. 2017. Available from: http://www.who.int/mediacentre/factsheets/fs 311/en/

25.Soewondo $P$, Oemardi $M$, Hospital $M$. Prevalence of Metabolic Syndrome Using NCEP / ATP III Criteria in Jakarta , Indonesia: The Jakarta Primary Noncommunicable Disease Risk Facto. 2014;(October 2010).

26.Wiardani NK, Arsana IWJ. Kejadian Sindroma Metabolik Berdasarkan Status Obesitas pada Masyarakat Perkotaan di Denpasar. Vol. 2, Jurnal IImu Gizi. Denpasar: Jurnal IImu Gizi; 2011. p. 12938.

27. Xi B, Liang Y, He T, Reilly KH, Hu Y, Wang $Q$, et al. Secular trends in the prevalence of general and abdominal obesity among Chinese adults, 1993-2009. Obes Rev. 2012;13(3):287-96.
28.Wiardani NK, Adiatmika IPG, D DPP, Tirtayasa K. Related Factors Increased Obesity Prevalence in Adult Women in Denpasar City , Bali. Indian J Publich Heal Res Dev. 2018;9(6)(4):422-8.

29.Silva MH, Jesus MCP De. Obesity in Adult Women: Home-based Cross-sectional Study. Online Brazilian J Nurs ( OBJN). 2014;13(3):302-10.

30.Naja $F$, Hwalla N, Itani L, Karam S, Mehio Sibai A, Nasreddine L. A Western dietary pattern is associated with overweight and obesity in a national sample of Lebanese adolescents (13-19 years): A cross-sectional study. Br J Nutr. 2015;114(11):1909-19.

31.Carlson SA, Fulton JE, Pratt M, Yang Z, Adams EK. Inadequate Physical Activity and Health Care Expenditures in the United States. Prog Cardiovasc Dis [Internet]. 2015;57(4):315-23. Available from: http://dx.doi.org/10.1016/j.pcad.2014.08.002

32.Suryana AL, Olivia Z. Asupan Makan Dan Profil Lipid Pada Pegawai Dengan Status Gizi Obesitas Dan Status Gizi Normal. In: Seminar Hasil Penelitian dan Pengabdian Masyarakat BOPTN. Jakarta; 2016. p. 5762.

33.Maria C.Linder. Nutritional Biochemeistry and metabolism: with Clinical applications. 2 th. Linder M, editor. New York: Elsevier Inc.; 1992. $603 p$.

34. Lamb KE, Thornton LE, Olstad DL, Cerin E, Ball K. Associations between major chain fast-food outlet availability and change in body mass index: A longitudinal observational study of women from Victoria, Australia. BMJ Open. 2017;7(10):1-9.

35. Vernarelli JA, Mitchell DC, Rolls BJ, Hartman TJ. Dietary energy density is associated with obesity and other biomarkers of chronic disease in US adults. Eur J Nutr. 2015;54(1):59-65.

36. Gurevich-Panigrahi T, Panigrahi S, Wiechec E, Los M. Obesity: pathophysiology and clinical management. Curr Med Chem. 2009;16(4):506-21. 